\title{
Model Structure Of Public Policy Based On Social Learning Onto Intolerant In Indonesia: Case in Pandeglang District, Banten
}

\author{
Kandung Sapto Nugroho ${ }^{1}$ \\ Universitas Sultan Ageng Tirtayasa Banten, Indonesia \\ kandungsapto@fisip-untirta.ac.id
}

\section{Rahayu $^{2}$}

Universitas Diponegoro Semarang, Indonesia rahayu_undip@yahoo.com

\section{Muhammad Adnan ${ }^{3}$}

Universitas Diponegoro Semarang, Indonesia adonan.sensei@gmail.com

\section{Hardi Warsono ${ }^{4}$}

Universitas Diponegoro Semarang, Indonesia hardie_wsn@gmail.com
E-ISSN (2721-0642)

Recieved:

May 082020

Revised:

July 272020

Accepted:

August 032020

Doi Number

10.37950/ijd.v2i2.53

\begin{abstract}
This research aims to design a model of public policy drafting in governance that can ensure the continuity of democratic principles. The principle of justice and equality both economically, socially, and politically are these foundations of democracy. If this principle is applied in the running of the government management process will be able to guarantee every individual citizen so that good governance is achieved. This approach of research with Positivistic with survey method through a closed questionnaire that has been done test validity, normality, reliability of the questionnaire to the leader of regional device organization in Pandeglang District government environment. This research will contribute to the mechanism of public policy retrieval with the primary mission to minimize potential conflicts. Please note that in 2011 in Pandeglang District, there had been a religious conflict in the case of Cikeusik Ahmadiyah, and by Tirto.id, Banten declared as the Intolerant region. The results of this study show that government bureaucracy in providing public services such as education, health, and religion has paid attention to the aspects of equalization and social justice, but it requires acceleration for bureaucracy related to the challenges of growing public problems. The influx of the 4.0 Industrial Revolution is aligned with the disruption era, the bureaucracy has to make adjustments to provide public service with typical generations of baby boomers, generation $X$, millennial generation even now already on $Z$ generation and Alpha generation are already native to the Internet.
\end{abstract}

Keywords: public policy, social equity, intolerant 


\section{Abstrak}

Penelitian ini bertujuan untuk merancang model penyusunan kebijakan publik dalam tata pemerintahan yang dapat menjamin kelangsungan prinsip demokrasi. Prinsip keadilan dan kesetaraan baik secara ekonomi, sosial, dan politik adalah fondasi demokrasi tersebut. Apabila prinsip ini diterapkan dalam menjalankan proses pengelolaan pemerintahan akan dapat menjamin setiap individu warga negara sehingga tercapai tata pemerintahan yang baik. Pendekatan penelitian ini bersifat positivistik dengan metode survei melalui angket tertutup yang telah dilakukan uji validitas, normalitas, reliabilitas angket kepada pimpinan perangkat perangkat daerah di lingkungan Pemerintah Kabupaten Pandeglang. Penelitian ini akan berkontribusi pada mekanisme pengambilan kebijakan publik dengan misi utama meminimalisir potensi konflik. Perlu diketahui bahwa pada tahun 2011 di Kabupaten Pandeglang pernah terjadi konflik agama dalam kasus Ahmadiyah Cikeusik, dan oleh Tirto.id, Banten dinyatakan sebagai Daerah Intoleran. Hasil penelitian ini menunjukkan bahwa birokrasi pemerintah dalam memberikan pelayanan publik seperti pendidikan, kesehatan, dan agama telah memperhatikan aspek pemerataan dan keadilan sosial, namun diperlukan percepatan birokrasi terkait dengan tantangan permasalahan publik yang semakin berkembang. Masuknya Revolusi Industri 4.0 ini selaras dengan era disrupsi, birokrasi harus melakukan penyesuaian untuk memberikan pelayanan publik dengan tipikal generasi baby boomer, generasi $X$, generasi milenial bahkan sekarang sudah ada generasi $\mathrm{Z}$ dan generasi Alpha sudah asli Internet.

Kata kunci: kebijakan publik, keadilan sosial, intoleran

\section{Introduction}

Social justice became an interesting issue to research. In Indonesia, social justice problems are enshrined in the base of the country Pancasila to the five social justices that read the whole Indonesia communities. According to (World Bank, 2006), "[Social] equity means equal access to the opportunities that allow people to pursue a life of their choosing and to avoid extreme deprivations in outcomes" - that is, equality in "rights, resources and voice". According to (IMF, 2007), "Equality of Rights refers to Equality under the law, whether customary or statutory. Equality of resources refers to Equality of opportunity, including Equality of access to human capital investments and other productive resources and markets. Equality of voice captures the ability of Social Equity and Development to influence and contribute to the political discourse and the development process ". However, often the implementation is not suitable for the purpose. According to (Buss \& Ahmed, 2015), the failure to achieve social equity, taken in a development context, also has many meanings, hence the concept of social exclusion is in wide use. "Social exclusion describes a process by which certain groups are systematically disadvantaged because they are discriminated against based on their 
ethnicity, race, religion, sexual orientation, caste, descent, gender, age, disability, HIV status, migrant status or where they live. According to (Frederickson, 1990) in (Esquith, 1997), that public administration not only longer discussed efficiency, economical but also discussing on social equity.

Social justice is a state obligation to citizens in every kind and form of government service. This Government's efforts are as a form of service assurance to these citizens. According to (Presiden Republik Indonesia, 2009), public services are activities or series of activities to fulfill the needs of services following the laws and regulations for every citizen and resident of goods, services, as well as administrative services provided by public service providers. One of the items of public service is the guarantee of independence to embrace its religion and worship according to its belief. In 2011 in Pandeglang District, an Intolerasi event of Cikeusik was a clash among religious Muslims. Based (BPS Pandeglang, 2019) showed that in Pandeglang District there is no place of worship other than the Muslim ummah. However, (Frederickson, 1990) suggested that one of the Government's selfless obligations is in terms of providing public service. In public service (Wang \& McFadden, 2016) explained that social equity was of special importance to public service because public service by its very nature is to be equitable and accountable to all citizens. Many have recognized that to achieve equity in public service, different individuals require different levels of resources and services.

In the Indonesian constitution of religious life regulated and secured in the Constitution 1945 chapter XI of religion article 29 paragraphs 2 mentioned that the State guarantees the independence of each population to embrace their religion and to worship according to its religion and belief. Its operationalization is in (Majelis, Rakyat, \& Indonesia, 1999) on Human rights and (Kemendagri, 2008) on the elimination of racial and ethnic discrimination. Indonesia has also ratified the ICCPR through Act No. 12 in 2005 on the ratification of the International Covenant on Civil and Political Rights.

Based on juridical, sociological, and historical conditions it is a necessity that the State should be present to ensure social justice in the case of worship for all religions in Indonesia. The presence of the Joint Regulation (Elfiandri, Perdamaian, 2015) on Minister of Religious Affairs and Minister of Home Affairs No. 9 in 2006 and No. 8 in 2006 on the Guidelines for implementation of regional head duties/Deputy regional chief in the maintenance of religious harmony, empowerment of religious harmony Forum. Also, the establishment of the synagogue as a revision of the SKB 1 in 1969 was a juridical form of the state but in its implementation, it often still causes horizontal friction between religious people. Based on data (BPS Pandeglang, 2019), in Pandeglang District with 35 Districts, there is no means of worship other than Muslims. However, there are non-Muslim residents. This strengthens the research result of (Tirto.id, 2018) that Banten declared as an intolerant area. According to this case, researchers want to contribute to making a design-build of policy formulation that can guarantee the basic value of democracy namely social justice to be a public value in public policy retrieval. 


\section{Theoretical Framework}

According to (Frederickson, 1990), "Social Equity was a phrase that comprehends an array of value preferences, organizational design preferences, and management style preferences. Social equity emphasizes equality in government services. Social Equity emphasizes responsibility for decisions and program implementation for public managers. Social Equity emphasizes responsiveness to these communities' necessity rather than public organizations itself. Social Equity emphasizes an approach to the study of Education for public administration that is interdisciplinary, applied, problemsolving in character, and sound theoretically". From the definition of understanding above it seems obvious that social justice is the obligation of the State to citizens in every kind and form of government service. This Government's efforts are as a form of service assurance to citizens. As explained by (LaShawn D. Moore and John C. Morris, 2009) stated: "The concept of social equity is central to the study and practice of public administration and has received a great deal of attention from scholars over the years. Using Stone's (1988) Typology of equity (items, recipients, and process) as our basis, the authors examine the extant literature related to social equity to determine how it has defined equity. Using content analysis, the find that all three of Stone's dimensions of equity are in the literature, and that definitions related to process issues are the most common in it ".

From the above understanding, it is explained that social justice in public administration practices covered the fairness of service items, fairness for service recipients, and fairness in the process of providing services as a guarantee of citizen rights. In the curriculum from (Naylor, Wilson-Gentry, \& Wooldridge, 2016) explained: What Is Social Equity? Social Equity has been defined as "The fair, just and equitable management of all institutions serving the public directly or by contract, and the fair and equitable distribution of public services, and implementation of public policy, and The commitment to promoting fairness, justice, and Equity in The formation of public policy", "Social Equity is fairness in the delivery of public services; It is egalitarianism in action-the principle that each citizen, regardless of economic resources or personal traits, deserves and has a right to be given equal treatment by the political system ".

Formally statutory (Kemendagri, 2008) on the elimination of racial and ethnic discrimination. Racial and ethnic disagreements are all forms of distinction, exclusion, limitation, or election based on race and ethnicity, resulting in the revocation or reduction of recognition, acquisition or implementation of human rights as well as basic freedoms inequality in civil, political, economic, social, and cultural affairs. The race is a group of peoples based on physical characteristics and lineage, whereas ethnicity is a human class based on belief, value, customs, customs, language norms, history, geography, and kinship relationships. According to (MAGUIRE, 2002) explained, "race also has its uses when discussing prejudice and discrimination". Thus, a race also used when discussing prejudice and discrimination. Social scientists consider racial terms to have a narrow meaning and this is applied as racism. 
According to (PASHA, 2000), declaring Human Rights (HAM) is the fundamental rights brought by a man from birth, which is inherent in his essence as God's grace. In this opinion, (Daudi Mwita Nyamaka, 2011) suggested that Human Rights are the rights given directly by God Almighty Creator. It appears that human rights are not the provision of the country to citizens, but the inherent right to belong to a person naturally given by the creator so that it must be respected, protected by individuals, communities, and or the state.

\section{Research Methodology}

Using the concept of social justice, this research observes to see the process of service, service items, and target services as a guarantee of the rights of citizens. This research uses a positivity approach with quantitative methods. The data collection techniques use closed questionnaires to then be carried out a test of validity, reliability, and normality of then sought frequency distribution. The interviewees were the stakeholders of policymakers in the executive environment of Pandeglang District government. With this data, researchers try to design a policy-drafting model based on the value of democracy that is social justice. This research focuses on the areas of social justice in public services. It is expected to reduce the potential for conflict in Indonesia.

Data validity test results show that all the questionnaire questions are valid above 0291 with table r-values so that the question item can be used as a datarieval tool. The value of the reliability test is 0.706 so it can be said to be reliable. The test value of normality indicates that the results of skewness-0.119:0.343 $=-0.34694$ and the results of kurtosis $0.736: 0.674=1.091988$ then the results obtained are between -2 to 2 . It can be concluded that the data produced in this study are distributed to normal data.

\section{Result and Discussion}

based on field data processing, the following is a recapitulation table of research results:

Table 1.

Recapitulation of Research Results

\begin{tabular}{|l|c|c|c|c|}
\hline \multirow{2}{*}{\multicolumn{1}{c|}{ Indicators }} & \multicolumn{3}{c|}{ Level of perception } \\
\cline { 2 - 5 } & $\begin{array}{c}\text { very } \\
\text { concur }\end{array}$ & agree & $\begin{array}{c}\text { less } \\
\text { concur }\end{array}$ & $\begin{array}{c}\text { dis- } \\
\text { agree }\end{array}$ \\
\hline Equity in Management Functions: Planning & $\sqrt{ }$ & $\sqrt{ }$ & & \\
\hline Equity in Management Functions: Organizing & $\sqrt{ }$ & $\sqrt{ }$ & & \\
\hline Equity in Management Functions: Actuating & $\sqrt{ }$ & $\sqrt{ }$ & & \\
\hline Equity in Management Functions: Controlling & $\sqrt{ }$ & $\sqrt{ }$ & \\
\hline Equity in Education Issue & $\sqrt{ }$ & $\sqrt{ }$ & \\
\hline Equity in Health Issue & $\sqrt{ }$ & $\sqrt{ }$ & $\sqrt{ }$ & \\
\hline Equity in Religion Issue & $\sqrt{ }$ & $\sqrt{ }$ & $\sqrt{ }$ & $\sqrt{ }$ \\
\hline Equity in Bureaucratic Structure & $\sqrt{ }$ & $\sqrt{ }$ & $\sqrt{ }$ \\
\hline
\end{tabular}


Volume 2, Issue 2, August 2020

http:/ /hk-publishing.id/ijd-demos

\begin{tabular}{|l|c|c|c|c|}
\hline Equity in Resources & $\sqrt{ }$ & $\sqrt{ }$ & $\sqrt{ }$ & \\
\hline Equity in Communication-Coordination & $\sqrt{ }$ & $\sqrt{ }$ & $\sqrt{ }$ & \\
\hline Equity in Bureaucratic Character & $\sqrt{ }$ & $\sqrt{ }$ & $\sqrt{ }$ & \\
\hline Equity in Bureaucratic Commitment to the Internal & $\sqrt{ }$ & $\sqrt{ }$ & \\
\hline Equity in Bureaucratic Commitment to the External & $\sqrt{ }$ & $\sqrt{ }$ & & \\
\hline Equity in Policy Input & $\sqrt{ }$ & $\sqrt{ }$ & $\sqrt{ }$ & \\
\hline Equity in Policy Process & $\sqrt{ }$ & $\sqrt{ }$ & & \\
\hline Equity in Policy Output & $\sqrt{ }$ & $\sqrt{ }$ & $\sqrt{ }$ & $\sqrt{ }$ \\
\hline Equity in Internal Policy Actors & $\sqrt{ }$ & $\sqrt{ }$ & $\sqrt{ }$ & $\sqrt{ }$ \\
\hline Equity in External Policy Actors & & &
\end{tabular}

Source: Researcher, 2019

Based on table 1, Aspects of the analysis are in terms of management functions. First, planning, can be known that according to the executive leaders in Pandeglang District government which stated to agree as much as $39.6 \%$ and $60.4 \%$ which expressed a very concur in the aspects of planning the public service of the regional government of Pandeglang District has noticed aspects of equitable equity of social justice. Second, organizing, that according to the executive leaders in Pandeglang District government which stated to agree as much as $47.9 \%$ and $52.1 \%$ who expressed a very concur in the aspect of organizing public services regional Government of Pandeglang District has noticed aspects of equitable equity of social justice. Third, actuating, that according to the executive leaders in Pandeglang District government, which stated concur as much as $58.3 \%$ and $41.7 \%$ who expressed a very concur in the actuating aspects of public service of Pandeglang District government has noticed aspects of equitable equity of social justice. Fourth, controlling that according to the executive leaders in Pandeglang District government, which stated to agree as much as $43.8 \%$ and $56.3 \%$ who said strongly agree that in the supervision aspect of Public Service of Pandeglang District government has noticed the aspect of equitable social justice.

In this aspect of management confirm the research results from (DeLeon, 1996; Vigoda, 2002; WILENSKI, 1986) Studied in public administration had suggested that public perceptions about the ethics and fairness of public officers and public agencies are positively related to the public's level of satisfaction with services received from them. In the absence of management function in Pandeglang District, government bureaucracy will be influenced by interaction with political activities, trust, ethics, and leadership. Bureaucratic activities cannot be separated from political activities in which bureaucracy as presented by (Vigoda-Gadot \& Drory, 2006) However, the proximity between bureaucracy and democracy, or between administration and politics, may also result in higher levels of organizational politics that may be easily observed by citizens and interpret into attitudes as well as actions in the democratic realm.

In the field of education, the research shows that according to the executive leaders in Pandeglang District government agreed to agree for 39.6\% and 54.2\% which 
expressed a very concur in public service in the field of education by the local government of Pandeglang District has noticed the aspect of equitable social justice and only $6.3 \%$ who said less concur. (Morris, 2009) delivered its wish of the facilitation of a' 'diversity of education' 'and an open public discourse on matters of importance to all individuals' "jointly" 'such that these issues may be regulated by' 'mutual agreement'. With the consensus together and make, that education is the necessity of the first then with equitable education will be able to maintain the fairness of education services. Where in Indonesia basic education is the responsibility of local government is medium education is the responsibility of the provincial government and higher education into the responsibility of the central government.

The results of the research in the field of health can be noted that according to the executive leaders in Pandeglang District government agreed to agree of $31.3 \%$ and $66.7 \%$ which expressed a very concur in public service in the field of health. The local government of Pandeglang District has noticed the aspect of equitable social justice implements these and only $2.1 \%$ who said less concur. Pandeglang in particular and Indonesia in general faced the same problem. Aligned with those delivered by (Houngbo et al., 2017), problems with governance in low-and middle-income countries (LMICs) can lead to ineffective and conditional donor aid, the waste of scarce resources, and societal disillusionment with public institutions. Moreover, it leads to a lack of available resources for, and accessibility to, health care, which affects the poor and marginalized mostly.

In religious areas, it can be known that according to the executive leaders in Pandeglang District Government stated that the agreement amounted to $47.9 \%$ and $45.8 \%$ expressed a very concur in the public service in the field of religion. These are implemented by the local government of Pandeglang District that has to consider the aspect of social justice equitable and then only $4.2 \%$ which stated that the lack of consent in the public service of religious areas on local government of Pandeglang District takes to pay attention to aspects of equitable social justice and only $2.1 \%$ that stated disagree. This shows that the area in Pandeglang still needs a guarantee of safety in the worship of all the religious people in Pandeglang. The guarantee is currently still not fulfilled entirely, referring to the Cikeusik events, the clash condition between the Ahmadiyah believer with Islam that inflicts casualties in 2011, seems to be used in the minds of society. There must be a reconstruction of religious significance, as expressed by (Yunus, 2014): The perspective of religion by placing religion as a source of conflict has led to various attempts to reinterpret then find common ground at a certain level with the hope to reduce conflicts among religious communities if there is mutual tolerance.

In the case of bureaucratic structure can be known that according to the executive leaders in Pandeglang District government said agree of $64.6 \%$ and $31.3 \%$ who expressed a very much concur structure bureaucracy of local government in Pandeglang District that have noticed the aspects of equitable equity of social justice. Then only $2.1 \%$ who stated less concur and $2.1 \%$ who stated disagree. This shows that 
the bureaucracy in the environment of Pandeglang District government still does not fully support efforts to ensure equitable social justice in public service. It is confirmed that the position of Echelon III and IV are still a lot of empty disturbing public service processes in Pandeglang neighborhood. Some vacant secretaries cannot be released with the political agenda because in 2020, in Pandeglang will be implemented regional head elections so that this charging becomes a pull of the public service causing uninterrupted. But the bureaucracy of our government as conveyed by(Uhaib \& Djani, 2018), In the field of domestic politics, strong political commitment and leadership are shown in connection with the restructuring of public administration by the government. With the realization of decentralization by issuing Law Number 22 of 1999 concerning regional governance which was later revised into Law number 32 of 2004 and revised into Local government law number 23 of 2014 which is still under the scope of the regional government. This has demonstrated strong public administration's commitment to serving the public.

In terms of resources, it is known that according to the executive leaders in Pandeglang District Government stated that the agreement amounted to $64.6 \%$ and $29.2 \%$ expressed the most agree that the resources of the local government of Pandeglang District have noticed the aspect of equitable equity of social justice, then only $6.3 \%$ who said less concur. This confirms the aspect of the bureaucratic structure, the vacancies of Echelon III and IV are in contact with the governance of resources and be it human resources, facilities, and infrastructure, natural resources. Similarly, political aspects, because next year is a political year cannot be denied because in the implementation of regional head elections, bureaucracy is often drawn to be involved in practical politics. It hopes that not lead to grand corruption as delivered by (Jain, 2001) in (Asamoah, 2017) generally refers to the acts of the political elite (selected officials) by which they exploit their power to make economic policies. As for the Regent incumbent and Vice Regent incumbent not/less harmonious and each allegedly strong will advance in the stage of Pandeglang district elections 2020.

From the aspect of communication-coordination can be noted that according to the executive leaders in Pandeglang District government which stated to agree as much as $72.9 \%$ and $25 \%$ expressed a very concur of communication and coordination. These are implemented by the local government of Pandeglang District and have noticed the aspects of equitable equity of social justice, then only $2.1 \%$ that said less concur. Often on a street-level bureaucracy that should be structured for performance enhancement precisely as delivered by $(S, 2017)$, street-level bureaucrats have their interest that was different from those of policymakers, triaging therefore sometimes undermines policy implementation.

The bureaucratic character is known that according to the executive leaders in Pandeglang District government which stated to agree the $72.9 \%$ and $22.9 \%$ who expressed a very concur character bureaucracy of the local government of Pandeglang District has noticed the aspect of equitable social justice, then only $4.2 \%$ who said less concur. ( et al., 2019) conveyed that the bureaucracy as a "collator" bureaucracy power is 
very easy to get excited and tempted to do "abuse of power" should give the ethical standards of the guidelines behave that are service-oriented. According to ("Politisasi Birokrasi Pemerintahan Desa Pada Era Reformasi,"2015) explained, the long history of Indonesia bureaucracy reflects the occurring bureaucracy polarization by government regime, with the result that all bureaucracy's line becomes an administration tool in performing is authority centralization. As a consequence, service tends to be addressed to the government (patron) by neglecting public service functions. It includes in village government scope, in which bureaucracy becomes a political machine, meanwhile serves as an effective controlling tool that limits social access to the public arena. It is undisputed that the bureaucracy is drawn to politics, on the other hand, the bureaucracy also deliberately politically; this is prevalent because the management of the bureaucracy spoil system has not fully merit system. This means the proximity of a bureaucrat with political leadership can still influence the employee's career path. A career path that is subject to non-professional factors, nonperformance, or based on the proximity of one with high officials is still happening so that the climate and poor working culture will worsen the time of this bureaucracy.

In the case of bureaucracy, commitment can be known that according to the executive leaders in Pandeglang District Government stated that the agreement amounted to $50 \%$ and $47.9 \%$ expressed a very concur in the internal commitment of the Pandeglang District government bureaucracies have noticed the aspect of equitable social justice, then only $2.1 \%$ who stated less concur. This internal commitment might be enforced as is the law enforcement as conveyed by (Suparman, 2013), that to realize public service law enforcement, public service organizer apparatus, should avoid ordinary or conventional ways, but require extraordinary ways (progressive law enforcement) means to work with a determination that is not equal to "justify all sorts of ways". In the case of bureaucratic commitment to the external can be known that according to the executive leaders in Pandeglang District government said to agree $60.4 \%$ and there is a $39.4 \%$ expressed a very concur commitment to the external government bureaucracy of local governments of Pandeglang District that have noticed aspects of equitable social justice. Pandeglang District as conveyed by (Praswati, 2017), need encouragement for government innovations involving universities and the industrial world better known by the concept of Triple helix.

In terms of the policy, apply in input in the drafting of policy. It can be known that according to the executive leaders in Pandeglang District government expressed the agreement of $60.4 \%$ and $37.5 \%$ expressed a very agreed in the process of forming public policy bureaucracy government of Pandeglang District already pay attention to the input policy-based social justice, then only $2.1 \%$ expressed less concur. Community involvement in policy drafting is the necessity as and application of democratic principles, as presented (Yasir, 2015), that the availability of public consultation mechanisms was essential to build community involvement as well as forming public institution's openness. 
In case of the policy process can be known that according to the executive leaders in Pandeglang District government officials expressed a concur of 58.3\% and 39.6\% expressed a very concur in the process of forming a public policy of the government bureaucracies already pay attention to the policy process based on social justice, then only $2.1 \%$ expressed less concur. In policy sciences, (Lasswell, 1970) in (Engeli \& Allison, 2014) delivered conceived of the policy sciences as being problem-focused, that is, interested in the substantive societal issues and problems facing governments which they need to address through analyzing the processes of policy formulation and choices, as well as evaluating implementation and policy outcomes. Besides, Pandeglang government should be able to read the social problems facing the community.

In terms of the output of the policy can be known that according to the executive leaders in Pandeglang District government said to agree the amount of $64.6 \%$ and $35.4 \%$ expressed a very concur in the process of forming a public policy of Pandeglang government bureaucracies already pay attention to the policy based on social justice equitable. Policy Output is policy. (ISLAM, 2007; PAL, 2007) the policy was a course of action or inaction, chosen by public authorities to address a given problem or an interrelated set of problems. The policy must be built with responsibility and openness as conveyed ("Human potential development as a prerequisite of public policy efficiency," 2014), the basic need for the system of public policy, the one, which is responsible for its openness and dynamic nature, is efficiency. Once a formulated policy is implemented, as conveyed by (Akib, 2012), that the policy implementation was a visible activity after the legitimate briefing of a policy that includes the effort to manage inputs to produce output or outcomes for the community. Therefore, the policy of Pandeglang District government should be able to be efficient to ensure social justice for its society.

Regarding the internal actors the policy is known that according to the executive leaders in Pandeglang District government said agree of $66.7 \%$ and $25.0 \%$ expressed a very concur in the process of forming a public policy bureaucracy. The bureaucracy of Pandeglang District government already paid attention to internal actors policy-based social justice, then only $6.3 \%$ expressed less concur and $2.1 \%$ expressed disagree. Since the policy according to (Dye, 2013) in (Howlett \& Cashore, 2014), was "anything a government chooses to do or not to do", then the action taken by the actor is the government, and the government cannot own to involve the other party even though its export is government.

In the commitment of involvement of external actors policy can be known that according to the executive leaders in Pandeglang District government said agree of $72.9 \%$ and $18.8 \%$ expressed the very agree in the process of forming public policy bureaucracy of Pandeglang District government already paid attention to external actors policy based on social justice equitable. Then only $6.3 \%$ expressed less concur and $2.1 \%$ expressed disagree. Today the Government cannot manage the country, but the community should be involved in decision-making. As conveyed by (Radzik- 
Maruszak \& Bátorová, 2015), that citizens should not be perceived not only as voters and subjects of politics between elections but also as a group that has a legitimate, institutionalized right to have a say in governance. Therefore, the concept of collaborative governance becomes one of the alternative governance solutions. (Emerson, Nabatchi, \& Balogh, 2012) in (Ansell \& Gash, 2018), that collaborative governance as a "type of public governance system in which cross-boundary collaboration represents the predominant mode for the conduct, decision making, and activity between autonomous participants who have come together to achieve some collective purpose defined by one or more target goals.

Based on the results of the discussion, researchers are trying to develop a model for drafting a policy formulation that can guarantee the values of social justice, democracy, and social equality as follows:

\section{Figure 1: Model of public policy formulation to ensure social justice}

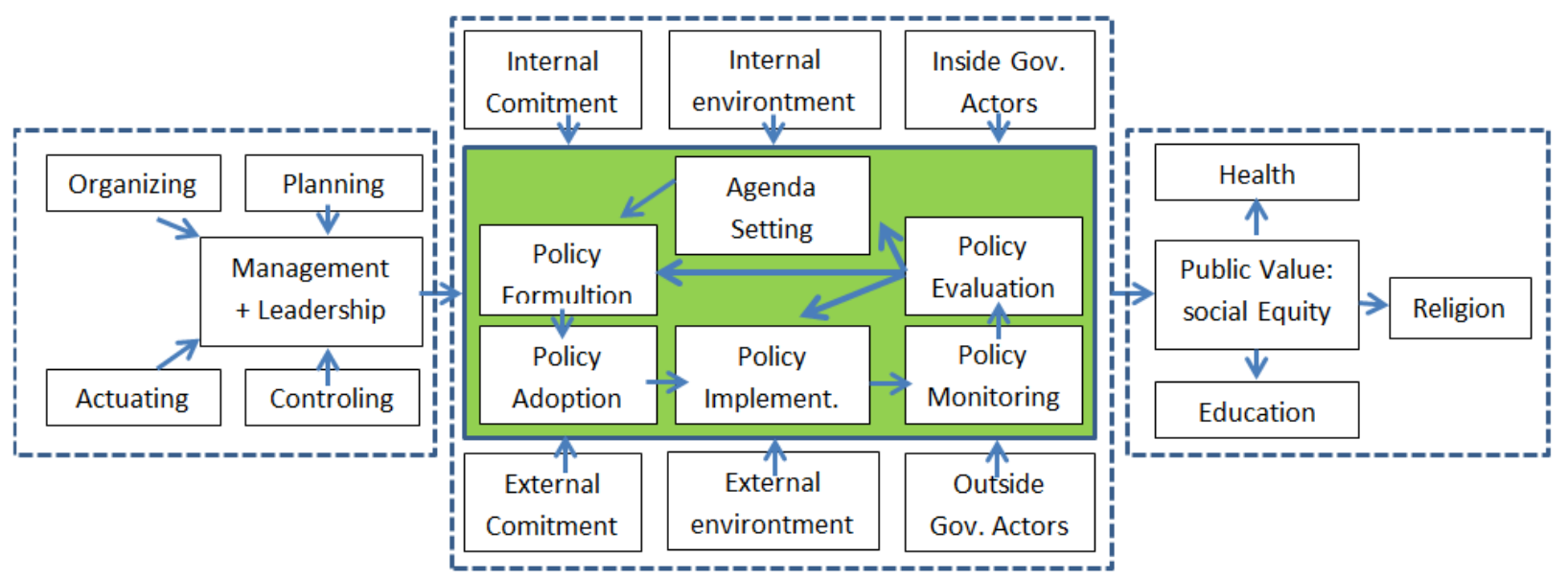

Source: Researcher, 2019

Discussing public administration will not be separated from politics because public policy is a political product. According to (Francis Mukosa1, 2017), the development of public policy is linked to the development of politics. Because of the need for management functions and the strong leaderships as holders of political power to run, an organization is a necessity, moreover for the public organization. Management functions such as planning, organizing, actuating, and controlling are the main function of the management that is mandatory. This will be the basis for measuring the performance of public institutions. Policy-making will always be a cycle starting from the agenda-setting that is the selection and sorting of public issues to become a public problem by the owner of the policy authority. Then proceed with the policy formulation process, legalization, and implementation of policy and followed by policy evaluation, where the evaluation output there are three things namely, public issues/issues selected, as well as its formulation and implementation.

All these processes are the decision-making process involving actors' policy in and outside the Government (stakeholder's policy) by having to consider internal and external environmental factors and supported with internal and external commitment 
policy executing agency. The established commitment should refer to public values such as efficiency, effectiveness, transparency, fairness, equitable, freedom, democracy, accountability so that it will be able to ensure the improvement of public services such as education, health, and religious services because the principle of all human beings is similar in God's eyes.

\section{Conclusion}

Based on the results of the research above, it can be concluded that the red tape of Pandeglang of Banten Indonesia in providing public services such as education, health, and religion already pay attention to aspects of equality and social justice. There are still some shortcomings that still occur but still within the boundary and part of the bureaucracy learning process in the system of values and challenges of public problems. That continues to develop such as the era of the revolution of 4.0 industry that is aligned with the era of the disruption so that the bureaucracy must make adjustments to provide public services where it is not only generations baby boomers, generation $X$, the millennial generation is even now a generation of the already native Internet. So that the findings are increasingly digitized the traditional community to accelerate modernization. The novelty condition on the characteristics of a more digital society should be further researched.

\section{About Author(s)}

Kandung Sapto Nugroho, Born in Kulon Progo Yogyakarta, September 18, 1978 is a lecturer at Faculty of Social and Political Sciences, Sultan Ageng Tirtayasa University Serang Banten. The author earned a bachelor's degree from Jenderal Soedirman University majoring in State Administration in January 2001. The Master's degree was obtained from Jenderal Soedirman University postgraduate Program in August 2009. Currently, he is taking a doctoral Program in public administration in Diponegoro University, Semarang. The subjects of the school include public service management, public policy, quantitative MPS, and qualitative MPS. The focus of his research has been on public policy, community empowerment, public service management, and corporate social responsibility. Works in the form of books is Good Governance of education experience in Banten Province ISBN: 9786029736595 (2013) which is the essence of the writer's thesis, The Practical Handbook of qualitative Research ISBN: 9786021733509 (2014) Cooperation with Graha Ilmu publisher, and the book electorate participation in Governor Election (2017) cooperation with the KPU of Banten Province. The authors hope these books can further add scholarly and beneficial treasures to the next generation.

Rahayu, was born in Semarang on 5 May 1962. Completed basic education from Elementary to Middle School in Semarang began at Don Bosko Elementary School Semarang, State Junior High School 5 Semarang (1977) and State Senior High School 3 Semarang (1981). Undergraduate education was attended at the Faculty of Law of 
Diponegoro University (1985), and for Master Degree was completed by Padjadjaran University graduate Program, Padjajaran Bandung (1995). Doctoral studies were completed at the Doctor of Law Science Program in Diponegoro University on 10 April 2010. A major master's degree was held from April 1, 2013. To pursue legal sciences with the specificity of international law and human rights, Rahayu always convey to continue to develop knowledge through various activities in accordance with Tri Dharma colleges. These are as follows: (1) Human Rights Course at Castan Centre for Human Right Law - Faculty of Law-Monash University-Melbourne-Australia-in 2004. (2) Sandwich Program at Flinders University-Adelaide-South Australia-in the year 2008 (3) Guest researcher at the Norwegian Centre for Human Rights-Oslo UniversityNorway-in 2009; and (4) Tailor made training on Socio Legal Studies at the Van Vollenhoven Institute-Leiden University-Netherlands-in 2010. In addition, these activities as a lecturer in the Faculty of Law in Diponegoro University since 1986 and the Head of Center for Human Rights Studies and international humanitarian law (PUSHAM-HHI) Faculty of Law in Diponegoro University. Nowadays, also often a speaker in various seminars, workshops and trainings, both at the regional, national and international level, relates to human rights issues. These writings spread across a variety of scientific journals and mass media related to active issues that occurred in the community.

Muhammad Adnan, was Born 16 September 1960. Lead as the head of Antiradicalism team in Diponegoro University, as a lecturer in the Department of Government Sciences Faculty of Social and Political Sciences Diponegoro University, Semarang. The subject of course is Anti-corruption policy; Religion and politics; Business and politics; and Networking Management. Particularly he interested in political and religious-themed research, comparative politics, and Global politics. He was active as the chief of regional manager of Nahdlatul Ulama (PWNU) Central Java for two periods (2000-2013). Now as deputy host of District Management Nahdlatul Ulama (PWNU) of Central Java. Muhammad Adnan holds a master's degree in political comparison from Hiroshima University, Japan. The study of Doctoral Program was completed in doctoral political science in Diponegoro University, Semarang, and Central Java. The background of his education was actually started by becoming students in the Pesantren Darun Nasiin, Malang, East Java. In 2015, he entered the exchange as a candidate for the general chair of Nahdlatul Ulama (PBNU).

Hardi Warsono, was born in Ngawi, East Java on 27 August 1964. He is a doctor in the field of public administration who works as a lecturer in the Department of Public Administration of the Faculty of Social and Political Sciences Diponegoro University, Semarang. He currently serves as the Dean of Faculty of Social and Political Sciences Diponegoro University as well as actively teaching in Faculty of Social and Political Sciences, Faculty of Public Health, Faculty of Economics and Business at the same university. Other activities are researching, active in the devotion to the community, as an interviewee, as a member of the selection committee of officials in various districts 
and cities. He also members of the bureaucracy reform team and once as a reviewer (team Evaluator) public Service Innovation Competition in Ministry of Administrative and Bureaucratic Reform of Indonesia Republic also as a member of the hospital supervisory board.

\section{Acknowledgements}

We gratefully thank for the government of Pandeglang District, which has given the opportunity of this research. Especially on the ranks of executives at the head of Office, Secretary of Office of the entire regional devices and experts staff of the Pandeglang's Regent of Banten Province Indonesia.

\section{References}

Ansell, C., \& Gash, A. (2018). Collaborative platforms as a governance strategy. Journal of Public Administration Research and Theory. https://doi.org/10.1093/jopart/mux030

Asamoah, J. K. (2017). The Role of Leadership in Combating Corruption in Decentralized Governance Structures of Ghana: An Empirical Study of GA South District Assembly. Review of Public Administration and Management. https:/ / doi.org/10.4172/2315-7844.1000228

Buss, T. F., \& Ahmed, U. (2015). Social equity and development. In Justice for All: Promoting Social Equity in Public Administration. https:// doi.org/10.4324/9781315703060-12

Daudi Mwita Nyamaka. (2011). Social Contract Theory of John Locke (1932-1704) in the Contemporary World. St. Augustine University Law Journal, 1(1).

DeLeon, P. H. (1996). Proceedings of the American Psychological Association, Incorporated, for the year 1995: Minutes of the annual meeting of the Council of Representatives: August 10 and 13, 1995, New York, NY, and February 16-18, 1996, Washington, DC. American Psychologist. https://doi.org/10.1037/0003066x.51.8.805

Dye, T. R. (2013). Understanding Public Policy, Fourteenth Edition. United State: Pearson Education.

Elfiandri, Perdamaian, F. R. (2015). Peraturan Bersama Menteri Agama dan Menteri Dalam Negeri. Jurnal RISALAH,.

Emerson, K., Nabatchi, T., \& Balogh, S. (2012). An integrative framework for collaborative governance. Journal of Public Administration Research and Theory. https://doi.org/10.1093/jopart/mur011

Engeli, I., \& Allison, C. R. (2014). Conceptual and Methodological Challenges in Comparative Public Policy. In Comparative Policy Studies. https:// doi.org/10.1057/9781137314154.0004

Esquith, S. L. (1997). John Rawls and the recent history of public administration. Journal of Management History (Archive). https:/ / doi.org/10.1108/13552529710191162 
Francis Mukosa1, B. M. \& M. K. (2017). What is Public Policy? How is it relatedto the law? Imperial Journal of Interdisciplinary Research, 3(9), 1. Retrieved from http:/ / www.onlinejournal.in

Frederickson, H. G. (1990). Public Administration and Social Equity. Public Administration Review. https://doi.org/10.2307/976870

Houngbo, P. T., Coleman, H. L. S., Zweekhorst, M., De Cock Buning, T., Medenou, D., \& Bunders, J. F. G. (2017). A model for good governance of Healthcare Technology Management in the public sector: Learning from evidence-informed policy development and implementation in Benin. PLoS ONE. https:// doi.org/10.1371/journal.pone.0168842

Howlett, M., \& Cashore, B. (2014). Conceptualizing Public Policy. In Comparative Policy Studies. https://doi.org/10.1057/9781137314154_2

Human potential development as a prerequisite of public policy efficiency. (2014). Studia Humanitatis.

ISLAM, N. (2007). RE-CONCEPTUALIZING PUBLIC POLICY PROCESS: REVIEW OF CONCEPTS AND MODELS. Lahore Journal of Policy Studies, 1(1), 7. Retrieved from http:/ / www.lahorejournalofpolicystudies.org/LJPS 1-1.pdf

Jain, A. K. (2001). Corruption: A Review. Journal of Economic Surveys. https:// doi.org/10.1111/1467-6419.00133

Kemendagri, K. D. N. R. I. (2008). Undang-Undang Nomor 40 Tahun 2008 tentang Penghapusan Diskriminasi Ras dan Etnis. Https://Kemendagri.Go.Id/Arsip/Detail/215/Undangundang-No-40-Tahun-2008.

LaShawn D. Moore and John C. Morris. (2009). An Examination of Social Equity and its Dimensional Emphasis in the Public Administration Literature. Journal of Public Management $\mathcal{E}$ Social Policy, 15(113). Retrieved from https://28b3dd4c-a-e2cc6547s-sites.googlegroups.com/a/jpmsp.com/new-jpmsp/15-1-

Moore.pdf?attachauth $=$ ANoY7co-

nyI993drOlITHgzRJccG0kgp6R99Q1jBSCtnFVoFhf0F5LMpLX_njKBzT9ewVhqpLL 5mmnHx9gwJlnPdElq3YXRGIu6254ZoGMF0Izkath2cHF3ftV_TOCMjluy9QfBS_A 8X8on1WmEooN0i6h

Lasswell, H. D. (1970). The emerging conception of the policy sciences. Policy Sciences. https:// doi.org/10.1007/BF00145189

MAGUIRE, J. (2002). SPORT WORLDS : A SOCIOLOGICAL PERSPECTIVE.

Majelis, K., Rakyat, P., \& Indonesia, R. (1999). Undang-Undang Nomor 39 Tahun 1999 Tentang Hak Asasi Manusia. Undang-Undang Republik Indonesia Nomor 39 Thn 1999 Tentang Hak Asasi Manusia.

Morris, M. (2009). Social justice and communication: Mill, Marx, and Habermas. Social Justice Research. https:/ / doi.org/10.1007/s11211-009-0091-6

Naylor, L. A., Wilson-Gentry, L. A., \& Wooldridge, B. (2016). Rethinking Connection: Master of Public Administration Student Perceptions of Transactional Presence. Journal of Public Affairs Education. https:/ / doi.org/10.1080/15236803.2016.12002227

PAL, L. A. (2007). Challenging the Performance Movement: Accountability, Complexity 
Volume 2, Issue 2, August 2020

http://hk-publishing.id/ijd-demos

and Democratic Values? By Beryl Radin. Governance. https://doi.org/10.1111/j.1468-0491.2007.00370_4.x

PASHA, "Musthafa Kamal." (2000). Pancasila dalam tinjauan Historis Yuridis dan Filosofis. Yogyakarta: Yogyakarta Citra Karsa Ma. Retrieved from http:/ / kin.perpusnas.go.id/DisplayData.aspx?pId=44688\&pRegionCode=UNIAD \&pClientId=125

Politisasi Birokrasi Pemerintahan Desa Pada Era Reformasi. (2015). JKAP (Jurnal Kebijakan Dan Administrasi Publik). https:/ / doi.org/10.22146/jkap.8335

Praswati, A. N. (2017). Perkembangan Model Helix Dalam Peningkatan Inovasi. Seminar Nasional Riset Manajemen \& Bisinis: Perkembangan Konsep Dan Riset EBusiness Di Indonesia.

Presiden Republik Indonesia. (2009). Undang-Undang RI No. 25 Tahun 2009 tentang Pelayanan Publik. Lembaran Negara RI Tahun 2009. Sekretariat Negara. Jakarta. https://doi.org/http://pelayanan.jakarta.go.id/download/regulasi/undangundang-nomor-25-tahun-2009-tentang-pelayanan-publik.pdf

Prihatini, J., Ma'ruf, M., \& Handayani, N. (2019). THE EMPOWERMENT IN ACCELERATION AND DEFENCE OF POVERTY IN DISTRICT OF INDRAMAYU, WEST JAVA, INDONESIA. https:/ / doi.org/10.32528/pi.v0i0.2476

Radzik-Maruszak, K., \& Bátorová, M. (2015). Citizen Participation and Engagement in Urban Governance: Perception of Finnish and Polish Local Officials. NISPAcee Journal of Public Administration and Policy. https:/ / doi.org/10.1515/nispa-2015-0005

S, Z. (2017). Street Level Bureaucrats as the Ultimate Policy Makers. Journal of Political Sciences \& Public Affairs. https://doi.org/10.4172/2332-0761.1000306

Suparman, H. (2013). Penegakan Hukum terhadap Penyelenggaraan Pelayanan Publik. Jurnal Wawasan Yuridika.

Uhaib, M., \& Djani, W. (2018). Indonesia Public Administration Reform in Supporting Good Governance. Review of Public Administration and Management. https:// doi.org/10.4172/2315-7844.1000256

Vigoda-Gadot, E., \& Drory, A. (2006). Handbook of Organizational Politics. Handbook of Organizational Politics. https://doi.org/10.4337/9781847201874

Vigoda, E. (2002). From responsiveness to collaboration: Governance, citizens, and the next generation of public administration. Public Administration Review. https:// doi.org/10.1111/1540-6210.00235

Wang, J., \& McFadden, E. S. (2016). The Absence of Social Equity Measurement in Municipal Service Privatization. State and Local Government Review. https:/ / doi.org/10.1177/0160323x15624474

WILENSKI, P. (1986). ADMINISTRATIVE REFORM - GENERAL PRINCIPLES AND THE AUSTRALIAN EXPERIENCE. Public Administration. https:/ / doi.org/10.1111/j.1467-9299.1986.tb00621.x

World Bank. (2006). Equity and Development. Equity and Development. https:/ / doi.org/10.1596/978-0-8213-6105-4

Yasir, A. (2015). Perumusan Kebijakan dan Peraturan Daerah Dengan Mekanisme 
Volume 2, Issue 2, August 2020 http://hk-publishing.id/ijd-demos

Konsultasi Publik. FIAT JUSTISIA. https:/ / doi.org/10.25041/ fiatjustisia.v6no2.327 Yunus, F. M. (2014). Konflik Agama Di Indonesia Problem Dan Solusi Pemecahannya. Substantia. 